\title{
Corporate Governance Against Recommendations: The Cases of the Strong Executive and the Strong Ownership
}

\author{
Král Pavel, Tripes Stanislav, Pirǒ̌eke Petr, Pudil Pavel
}

\begin{abstract}
There are several basic configurations of corporate governance according to the separation of ownership and control (Jensen's theory). Effective governance is described as a situation when an owner (or group of owners) keeps the right to ratify and monitor strategic decisions while management has the right to initiate and implement those decisions. There are two particular situations how this recommendation is partially broken and both situations are linked to CEO duality. The first case happens when an owner loses or does not exercise the right to monitor management of the organization and is termed as the strong executive. The second case is called the strong ownership and is distinguished by an owner taking over implementations of the decisions. The focus of the study was to explore particularly configurations of the strong executive and the strong governance. A mixed method research design was chosen to explore the differences between the basic governance configurations. The sample was chosen by purposive sampling and covered a hundred for-profit organizations of all size and from all sectors of economy. The data were collected through interviews with representatives, mainly members of top management. We revealed that both of these configurations can bear good corporate performance but also bigger risks. The strong executive is typical for organizations with dispersed ownership or a publicly owned organization and the performance of the organization is fully dependent on competencies but also personalities of managers. This configuration contains a high risk of misuse of authority. The strong ownership is effective in small organizations while in a larger organization leads to an overexertion of owners and low performance because they usually face problems to keep focus on the strategic issues of the organization.
\end{abstract}

Key words: Corporate governance, strong executive, strong ownership, CEO duality, Governance in CEE countries

\section{INTRODUCTION}

The effective governance is characterized by separation of ownership and control. The level of separation is determined by the decomposition of decision making process combined with matching the steps of decision making process to owners and managers (Fama \& Jensen, 1983, Goranova et al, 2007). Jensen and Fuller (2002) decompose the decision making process into four main phases: initiation, ratification, implementation and monitoring. Ratification and monitoring are linked to exercise of control rights while initiation and implementation are linked to executive and managerial rights. The optimum is described when shareholders (or owners) hold control rights and executive rights are designated to managers. Moreover, this optimum is based on clearly outlined organizational elements representing interest of the shareholders. The shareholders are represented by control body (board of trusties, supervisory board, supervisory 
council, etc.) while managers carry implement ratified strategies. (Crosslan \& Hambrick, 2007). There are clear rules for a nomination into the control body and also for an election or an appointment of executives. In other words, good governance is based on rules precisely defining the discretionary trust of the managers on one side and assuring the control mechanism for shareholders. Thus, the roles of managers and shareholders are clearly outlined and do not overlap. This governance configuration is in accordance with the most acknowledged codes of good governance, such as Sarbaness-Oxley Act of 2002 or OECD Principles of Good Governance (2004). Only such governance configuration is assessed as the effective governance.

Central and Eastern Europe (CEE) countries went through significant changes in previous twenty years and these changes significantly influenced entire economy. Corporate governance in these countries is often not in coherence with corporate governance recommendation and codes successfully applied in well developed economies (Hashi, 2003; Meyer, 2003; Wright et al, 2005 , Son et al, 2011). This is caused by different development of appropriate corporate governance mechanisms and initial complete absence of necessary prerequisites such as appropriate legal structure or financial institutes (Wright, Buck, \& Filatotchev, 2005). One of the key reasons of difference development of CEE countries is identified in speed of transformation. Meyer (2003) denotes that "The transition economies in Central and Eastern Europe have privatized their economies at an unprecedented speed in the 1990s" (Meyer, 2003, p. 31). Meyer sees the main problem in the relation between owners and managers. Either managers or owners often crossed the lines of their authorities and meddled in the rights of the other stakeholders. As a result, it is likely that CEE countries may thus develop unique forms of corporate governance. In our paper, we focus on two particular types of corporate governance where the rules of good corporate governance are breached.

The rules of good corporate governance are very often breached by CEO duality. This duality is frequent in CEE countries (Aguilera \& Jackson, 2010). Very often asked question is linked to the relation between CEO duality and organizational performance. The relation has not been successfully clarified yet and the results of the studies are inconsistent (Boyd, 1995). Elsayed (2007) examined the influence of CEO duality on corporate performance. He found that the impact of CEO duality varies across industries. Moreover, he discovered a relation of corporate performance and CEO duality when corporate performance was low. In contrast, Peng et al (2010) found that $\mathrm{CEO}$ duality positively moderates firm performance in private-owned enterprises while it negatively moderate firm performance in state-owned enterprises. Thus, the form of ownership appears to be a significant factor. This idea was partially supported by Chang and Zhang (2011). They revealed that institutional investors buy the shares of the firms with good governance quality governance structure. In addition, board configuration itself is another factor influencing corporate performance (Muller-Kahle \& Lewellyn, 2011). Large discretion of the CEO may lead to better performance of the manager and also the organization and thus the large discretion can be beneficial to the owners (Rodrigues \& António, 2011). The risk comes from the asymmetry of information between the $\mathrm{CEO}$ and the owners. The CEO can misuse the asymmetry of information in his or her own profit. To provide more in-depth analysis of CEO duality we distinguish two types of duality depending on a shift of rights in decision making process.

The first case of CEO duality occurs when shareholders are excluded from monitoring and is termed as the strong executive. It appears when an executive organ carries out the monitoring 
functions while shareholder's role becomes formal but symbolic (Boyd, 1994). Consequently, the relation between shareholders and managers weakens (Monem, 2011). In extreme case, shareholders have no control over the organization and are "in the hands" of the managers. The described situation is a possible consequence of CEO duality when appointed manager takes over monitoring rights, for instance CEO becomes the head of the control authority (Kong-Hee et al, 2009). There are several causes of the exclusion. First cause is linked with the speed of transformation and privatization (Meyer, 2003, Dharwadkar et al, 2008). The speed of privatization was too fast to allow separation of managerial and control rights. Second, effective monitoring is also influenced by the structure and number of shareholders. For example, there is a big difference between dispersed ownership of thousand shareholders, ownership of state and ownership of one or few individual shareholders. The more there are shareholders and the more dispersed is the ownership the bigger is probability of exclusion shareholders from effective monitoring. Third, a personality of CEO plays a significant role (Horner, 2010). After the communism era there was a lack of experienced managers and almost anyone could become a CEO. Hence, many incompetent people ended up as CEOs and they did not allow shareholders to control. And finally, the level of shareholder's attention to monitoring depends on deviation in performance of an organization (Tuggle et al., 2010). Performance increase reduces shareholder's attention to monitoring and thus strengthens the discretion of managers. Paradoxically, the better is the organizational performance the bigger is the possibility of losing the control of shareholders and vice versa.

Another case of CEO duality is characterized by owners involved in management of the organization and is termed as the strong ownership. The owner is not separated from the executive, takes over the managerial rights and is represented in all bodies of an organization (Harris \& Helfat, 1998). Typically, the shareholder takes over the step of implementation. Thus, the shareholder holds the managerial functions (Kang \& Zardkoohi, 2005). In such configuration, it is necessary to emphasize clear outline of the governance structure (Pirožek, 2007). The roles of the owners and executive must be clearly stated and must not overlap. There should be rules for nomination into the control body and also clear rules for appointment of executives. Yet, the discretionary trust of the managers should be clearly stated. The strong ownership is a typical governance configuration for small enterprises or family companies. However, there is a turning point in expansion of a firm from which it is impossible for the owner to handle all the managerial duties and the owner should appoint professional CEO. The last case of governance configuration occurs when these recommendations are broken and is termed as the ineffective governance. This is represented by very unclear or vague governance structure where roles of shareholders and managers are not defined at all.

\section{METHODOLOGY}

We used a mixed method research design to answer the research question. Specifically, we employed concurrent equal status design as we collected and processed quantitative and qualitative data at the same time (Leech \& Onwuegbuzie, 2009). We combined a qualitative data obtained through interviews with quantitative obtained through interviews and document analysis. 100 Czech for-profit organizations were chosen to be involved in the study. Purposive sampling 
was chosen to achieve the optimal representativeness (Teddlie \& Yu, 2007): the organizations represented all sectors in accordance with the proportion in the Czech economy (Blažek et al, 2011) which was done on the basis of NACE codes. There was also a balance of domestically and internationally owned organizations. Moreover, the sample comprised organizations of all sizes. The interviews were conducted with representatives of the organizations, usually with a member of top-level management. The interviews were recorded, analyzed and particular variables were transformed to category scale. Financial and other quantitative data were collected from available corporate documents. The quantitative data were processed employing MS Excel and SPSS while qualitative data obtained through interviews helped to interpret the results.

The objective of the study was to survey the differences between the main governance configurations: the effective governance, the strong executive and the strong ownership. We used the quantitative data to test two hypotheses. Our first hypothesis was based on findings of differences in governance between CEE countries and well developed countries. Previous studies indicate that CEE countries may have developed different governance especially in relations between owners and managers. Hence, we tested the relation between the owner's residency and the governance configuration. The second hypothesis is derived from presumption that the effective governance configuration brings better firm performance in comparison with other governance configurations. Thus, we tested the relation of the governance configuration and the firm performance.

H1: There is a difference in the governance configuration between domestic and internationally owned organizations.

H2: The effective governance configuration leads to better firm performance.

Return on Assets indicator ( $\mathrm{ROA}$ ) was used as the criterion of firm performance. ROA is a preferred measure to examine the relation between performance and corporate governance because it is not affected by leverage, extraordinary items and other discretionary items (Core, Guay, \& Rusticus, 2006). In coherence with this finding, we found numerous studies examining corporate governance where ROA was used as a performance measure (Balabat, Teylor \& Walter, 2004; Brown \& Caylor, 2009; Haniffa \& Hudaib, 2006; Christensen, Kent, \& Stewart, 2010; Kiel \& Nicholson, 2003; Lehmann \& Weigand, 2000). The financial data were acquired from official annual reports.

Further on, qualitative data were used to scrutinize the cases of the strong executive and the strong ownership, since the impact of those two configurations is not clear and our aim was to explore these two configurations. We were looking mainly for the circumstances where these governance configurations inhibit or improve the firm performance and explored these cases.

\section{RESULTS}

We successfully collected data from 83 organizations from the sample of hundred selected organizations what gives the response rate of $83 \%$. Such a big response rate was reached due to interview-based survey. Seventeen organizations were excluded from the survey because they were not able to provide the data we requested. The most common reason of exclusion an organization from the survey was linked to the low transparency and unavailability of financial 
statements. Moreover, some of the organizations did not publish the annual report even though it was their legal liability. Nevertheless, 83 organizations is a sufficient sample to provide satisfactory results.

The basic organizational characteristics show the representativeness of the sample. 23 organizations were small enterprises, 20 were medium enterprises and 40 were large enterprises. The legal form of the sample organizations reflects the population in the Czech Republic too. The largest number of organizations (27) comes from the manufacturing sector which also reflects the situation in the Czech economy. The sample comprised of domestically and internationally owned organizations - 32 organizations were owned by domestic owners and 51 had an international owner. Table 1 depicts the distribution of the organizations according to NACE codes and domestic/internationally owned enterprises. Two main legal forms dominated the sample - limited liability company (LTD) (45 in total) and joint stock company (JSC) (35 in total). Cooperative association as rather traditional legal form of ownership in the Czech Republic was represented by two organizations only. Further on, we analyzed financial statements to evaluate performance of the organizations. Return on Assets indicator (ROA) was used to measure the corporate performance. Average ROA in the sample was $4.9 \%$ with minimum of $-91 \%$ and maximum of $61 \%$. The standard deviation of the sample was .1687. The average ROA was used to distinguish the organizations with above average ROA and below average ROA. Overall, 38 organizations reached above average ROA and 45 were below the average.

Tab. 1 - The distribution of the sample NACE coding. Source: Own research

\begin{tabular}{|c|c|c|c|c|}
\hline \multicolumn{2}{|r|}{ NACE } & Domestic & International & Total \\
\hline A & Agriculture, forestry and fishing & 1 & 0 & 1 \\
\hline $\mathrm{C}$ & Manufacturing & 8 & 19 & 27 \\
\hline $\mathrm{D}$ & $\begin{array}{l}\text { Electricity, gas, steam and air condi- } \\
\text { tioning supply }\end{array}$ & 2 & 1 & 3 \\
\hline $\mathrm{E}$ & $\begin{array}{l}\text { Water supply; sewerage; waste manage- } \\
\text { ment and remediation activities }\end{array}$ & 1 & 0 & 1 \\
\hline $\mathrm{F}$ & Construction & 4 & 3 & 7 \\
\hline G & $\begin{array}{l}\text { Wholesale and retail trade; repair of } \\
\text { motor vehicles and motorcycles }\end{array}$ & 2 & 6 & 8 \\
\hline $\mathrm{H}$ & Transporting and storage & 2 & 1 & 3 \\
\hline I & $\begin{array}{l}\text { Accommodation and food service } \\
\text { activities }\end{array}$ & 1 & 1 & 2 \\
\hline $\mathrm{J}$ & Information and communication & 2 & 3 & 5 \\
\hline $\mathrm{K}$ & Financial and insurance activities & 0 & 7 & 7 \\
\hline M & $\begin{array}{l}\text { Professional, scientific and technical } \\
\text { activities }\end{array}$ & 5 & 3 & 8 \\
\hline $\mathrm{N}$ & $\begin{array}{l}\text { Administrative and support service } \\
\text { activities }\end{array}$ & 0 & 3 & 3 \\
\hline
\end{tabular}




\begin{tabular}{|c|l|c|c|c|}
\hline P & Education & 1 & 1 & 2 \\
\hline Q & Human health and social work activities & 1 & 2 & 3 \\
\hline R & Arts, entertainment and recreation & 2 & 1 & 3 \\
\hline \multicolumn{2}{|c|}{ Total } & 32 & 51 & 83 \\
\hline
\end{tabular}

The objective of the study was to survey the differences between the main governance configurations: the effective governance, the strong executive and the strong ownership (ineffective governance was observed in an only organization which prevents us from doing general conclusions about the consequences). First of all, exact classification was crucial for further work. The effective governance was classified in 49 organizations, 18 organizations were characterized as having the strong ownership, 15 organizations were classified as having the strong executive, thus leaving the only organization with the ineffective governance. Table 2 depicts the basic characteristics of the sample segmented according to the governance configuration and in addition, the organizations were subdivided into domestic and international organizations and split by the legal form. The table shows that the effective governance prevails in international organizations. The ratio of prevalence of individual governance configurations is similar in both major legal forms. The frequency of strong executive was bigger in domestic companies. The difference is more obvious using ratios - the strong executive was observed in $28 \%$ of domestic organizations and only in $11 \%$ of international organizations. Consequently, the difference between domestic and international organizations was statistically tested. We reject the equality of domestic and international organizations $(\alpha=.044)$ and thus, we confirm the difference in governance between domestic and international organizations. This gives us the support for the first hypothesis.

Tab. 2 - Sample according to legal form and corporate governance approach. Source: Own research

\begin{tabular}{|c|c|c|c|c|c|c|c|c|c|}
\hline \multicolumn{10}{|c|}{ Corporate governance configuration - absolute numbers } \\
\hline \multirow{2}{*}{$\begin{array}{l}\text { Size of the } \\
\text { organization }\end{array}$} & \multicolumn{2}{|c|}{$\begin{array}{c}\text { Effective } \\
\text { governance }\end{array}$} & \multicolumn{2}{|c|}{$\begin{array}{c}\text { Strong } \\
\text { Ownership }\end{array}$} & \multicolumn{2}{|c|}{ Strong executive } & \multicolumn{2}{|c|}{$\begin{array}{l}\text { Ineffective } \\
\text { governance }\end{array}$} & \multirow[b]{2}{*}{ Total } \\
\hline & $\begin{array}{c}\text { Domes- } \\
\text { tic }\end{array}$ & $\begin{array}{c}\text { In- } \\
\text { terna- } \\
\text { tional }\end{array}$ & $\begin{array}{l}\text { Domes- } \\
\text { tic }\end{array}$ & $\begin{array}{c}\text { In- } \\
\text { terna- } \\
\text { tional }\end{array}$ & $\begin{array}{l}\text { Domes- } \\
\text { tic }\end{array}$ & $\begin{array}{c}\text { In- } \\
\text { terna- } \\
\text { tional }\end{array}$ & $\begin{array}{l}\text { Domes- } \\
\text { tic }\end{array}$ & $\begin{array}{c}\text { In- } \\
\text { terna- } \\
\text { tional }\end{array}$ & \\
\hline $\begin{array}{l}\text { Joint stock } \\
\text { company }\end{array}$ & 3 & 16 & 1 & 8 & 4 & 3 & & & 35 \\
\hline $\begin{array}{l}\text { Limited } \\
\text { liability com- } \\
\text { pany }\end{array}$ & 12 & 15 & 5 & 4 & 5 & 3 & 1 & & 45 \\
\hline $\begin{array}{l}\text { Cooperative } \\
\text { association }\end{array}$ & 1 & 1 & & & & & & & 2 \\
\hline $\begin{array}{l}\text { Other legal } \\
\text { form }\end{array}$ & & 1 & & & & & & & 1 \\
\hline Total & 16 & 33 & 6 & 12 & 9 & 6 & 1 & 0 & 83 \\
\hline
\end{tabular}


Further on, we surveyed the effect of governance configuration on corporate performance. We did not find statistically significant differences between ROA of organizations with different governance configurations. Average ROA in the sample was $4.9 \%$ with minimum of $-91 \%$ and maximum of $61 \%$. The standard deviation of the sample ROA was .1687. The average ROA was used to distinguish the organizations with above average ROA and below average ROA. Overall, 38 organizations reached above average ROA and 45 were below the average. Generally, the effective governance results in more frequent occurrence of above average ROA (26 out of 49 cases which is $53 \%$ ), while strong ownership shows the worst impact on ROA (only five of eighteen cases which is $28 \%$ ). However, statistical tests do not prove the significance of the relations between governance configuration and ROA. Hence, we do not have a statistical support for our second hypothesis.

Next, we divided the sample according to governance approach and surveyed each governance configuration. We considered the legal form of organizations as a criterion to help us distinguish between the particular governance configurations. 19 from 35 joint stock companies in our sample were classified as having the effective governance; nine firms had the strong ownership and seven the strong executive which corresponds with the overall ratio. When we divided the sample according to ROA and international/domestic ownership, we revealed interesting findings. The strong executive resulted in above average ROA in five of seven cases. Those cases were represented more by domestic owners and all those cases were large companies. Table 3 demonstrated the distribution within joint stock companies.

Tab. 3 - The Joint stock company and its governance configuration. Source: Own research

\begin{tabular}{|c|c|c|c|c|c|c|c|c|c|}
\hline \multicolumn{10}{|c|}{ The Joint stock company - governance configuration } \\
\hline \multirow{2}{*}{$\begin{array}{c}\text { Size } \\
\text { of the } \\
\text { organi- } \\
\text { zation }\end{array}$} & \multicolumn{2}{|c|}{$\begin{array}{c}\text { Effective } \\
\text { governance }\end{array}$} & \multicolumn{2}{|c|}{$\begin{array}{c}\text { Strong } \\
\text { ownership }\end{array}$} & \multicolumn{2}{|c|}{$\begin{array}{c}\text { Strong } \\
\text { executive }\end{array}$} & \multicolumn{2}{|c|}{$\begin{array}{l}\text { Ineffective } \\
\text { governance }\end{array}$} & \multirow[b]{2}{*}{ Total } \\
\hline & $\begin{array}{c}\text { Above } \\
\text { average } \\
\text { ROA }\end{array}$ & $\begin{array}{c}\text { Under } \\
\text { average } \\
\text { ROA }\end{array}$ & $\begin{array}{c}\text { Above } \\
\text { average } \\
\text { ROA }\end{array}$ & $\begin{array}{c}\text { Under } \\
\text { average } \\
\text { ROA }\end{array}$ & $\begin{array}{c}\text { Above } \\
\text { average } \\
\text { ROA }\end{array}$ & $\begin{array}{c}\text { Under } \\
\text { average } \\
\text { ROA }\end{array}$ & $\begin{array}{c}\text { Above } \\
\text { average } \\
\text { ROA }\end{array}$ & $\begin{array}{c}\text { Under } \\
\text { average } \\
\text { ROA }\end{array}$ & \\
\hline Small & 1 & 1 & 1 & & & 1 & & & 4 \\
\hline Medium & & 2 & & 1 & & & & & 3 \\
\hline Large & 7 & 8 & 2 & 5 & 5 & 1 & & & 28 \\
\hline Total & 8 & 11 & 3 & 6 & 5 & 2 & 0 & 0 & 35 \\
\hline
\end{tabular}

We analyzed limited liability companies using the same perspective i.e. dividing according to level of ROA and ownership. We found different distribution of ROA depending on the governance configuration. The effective governance led in majority of cases to above average ROA whereas both strong ownership and strong executive resulted in below average ROA. We found a difference between domestic and internationally owned companies. All international LTDs with the strong ownership were characterized by below average ROA. The explanation was found in low trust in hired Czech managers. The representatives of international owners were occupied not only with the high level of control but they also participated in managerial duties. The only two successful organizations with strong ownership had a Czech owner and can be classified as family-controlled business. The overview of LTDs is depicted in table 4. 
Tab. 4 - The Limited liability company governance configuration. Source: Own research

\begin{tabular}{|c|c|c|c|c|c|c|c|c|c|}
\hline \multicolumn{10}{|c|}{ The Limited liability company - governance configuration } \\
\hline \multirow{2}{*}{$\begin{array}{c}\text { Size } \\
\text { of the } \\
\text { organiza- } \\
\text { tion }\end{array}$} & \multicolumn{2}{|c|}{$\begin{array}{l}\text { Effective gov- } \\
\text { ernance }\end{array}$} & \multicolumn{2}{|c|}{$\begin{array}{l}\text { Strong owner- } \\
\text { ship }\end{array}$} & \multicolumn{2}{|c|}{$\begin{array}{l}\text { Strong execu- } \\
\text { tive }\end{array}$} & \multicolumn{2}{|c|}{$\begin{array}{l}\text { Ineffective } \\
\text { governance }\end{array}$} & \multirow[b]{2}{*}{ Total } \\
\hline & $\begin{array}{c}\text { Above } \\
\text { average } \\
\text { ROA }\end{array}$ & $\begin{array}{c}\text { Under } \\
\text { average } \\
\text { ROA }\end{array}$ & $\begin{array}{c}\text { Above } \\
\text { average } \\
\text { ROA }\end{array}$ & $\begin{array}{c}\text { Under } \\
\text { average } \\
\text { ROA }\end{array}$ & $\begin{array}{c}\text { Above } \\
\text { average } \\
\text { ROA }\end{array}$ & $\begin{array}{c}\text { Under } \\
\text { average } \\
\text { ROA }\end{array}$ & $\begin{array}{c}\text { Above } \\
\text { average } \\
\text { ROA }\end{array}$ & $\begin{array}{c}\text { Under } \\
\text { average } \\
\text { ROA }\end{array}$ & \\
\hline Small & 6 & 5 & 1 & 3 & & 3 & & 1 & 16 \\
\hline Medium & 3 & 4 & 1 & 3 & 1 & 3 & & & 15 \\
\hline Large & 8 & 1 & & 1 & & 1 & & & 11 \\
\hline Total & 17 & 10 & 2 & 7 & 1 & 7 & 0 & 1 & 45 \\
\hline
\end{tabular}

\section{DISCUSSION AND CONCLUSION}

Although effective corporate governance configuration prevails we put our effort into other governance configurations, specifically the strong executive and the strong ownership. These configurations are not in accordance with recommendations of governance codes but they can also bear good results. The strong ownership was appropriate in small and medium enterprises what is in accordance with results of previous studies (Miller \& Le Breton-Miller, 2006). On the other hand, the strong ownership can easily develop in the situation when the owners fail to attend to strategic goals and are overburden by day-to-day routine. This is in coherence with Kang and Zardkoohi (2005) when long-term planning is displaced by day-to-day routine and monitoring rights are neglected. It is important for the owners to recognize such situation and to appoint professional management before they lose strategic focus. Yet, the owners must delegate only the right to initiate and to implement while they have to keep the right to ratify and to monitor. In our research, the strong ownership more often resulted in below average ROA. Majority of those organizations did not manage to appoint professional managers in the right moment and those organizations were the case of owners' overburden by day-to-day routine instead of focus on long term objectives. Furthermore, we discovered a phenomenon of the strong ownership within larger international organizations. We found the reasons in low trust in Czech environment and Czech managers when international owner tended to meddle into managerial rights of Czech managers. In conclusion, the strong ownership is usually effective in small (and especially family run) organizations while in larger organization leads to overexertion of owners and low performance.

The strong executive is the most unpredictable governance configuration. The majority of joint stock companies (five of seven) classified as having the strong executive produced above average ROA. The explanation was found in very competent managers leading those organizations. Moreover, the strong executive is desirable configuration in certain situation such as crisis management. However, a warning is necessary: strong executive makes owners dependent on the managers and therefore the personality of a manager is crucial (Horner, 2010) and there is a high risk of misuse of the authority. The strong executive also did not work in LTDs and smaller organizations. To illustrate, there are very well known corporate scandals caused by strong ex- 
ecutive. Enron scandal is probably the best known corporate scandal in the world and up-to-date scandal emerged in the Czech Republic last year. The largest Czech lottery company Sazka went bankrupt as a result of very strong executive - the CEO had almost unlimited power over the board.

Our study has its limitation. First limitation is caused by the size of the sample and thus, the generalization of the results. We identified 15 organizations with the strong executive and 18 organizations with the strong ownership which prevents us from making statistically significant results. On the other hand, using interviews allowed us to explain every case individually. Second limitation is perceived in ROA as performance indicator. Although it is recommended performance indicator for examining the relation between corporate governance and performance, international companies sometimes divert monetary resources to their mother companies for purposes of lowering their profit in the Czech Republic (and returning taxes in their original countries). And third, we calculated ROA for a single year. Series of ROA calculated for several consecutive years could help to eliminate year-to-year deviations in financial performance. Unfortunately, some of the organizations were not able to provide data for more than requested year and calculating ROA for several consecutive years would reduce the research sample. These limitations will be taken into consideration in future research design. Thus, our future research will be conducted with emphasis on enlarging the sample size and more detailed financial analysis.

Generally, we found prevalence of the effective governance configuration what points at gradual and steady application of corporate governance principles from well developed economies. On the other hand, $40 \%$ of organizations demonstrate governance configuration not corresponding to up to date corporate governance principals. We proved a difference between domestically and internationally owned companies since internationally owned companies displayed statistically significant higher ratio of the effective governance configuration. Nevertheless, we did not get the evidence that the only effective governance leads to good organizational performance. Even the strong executive and the strong ownership can assure good organizational performance, despite those configurations are not consistent with general recommendations. Our paper sheds light upon these two governance configurations, explores the conditions under which these configurations can be successful and, points at their risks and limitations.

\section{References}

1. Aguilera, R. V., \& Jackson, G. (2010). Comparative and International Corporate Governance. The Academy of Management Annals, 4 (1), 485-556. http://dx.doi.org/10.1080/19416520 .2010 .495525

2. Balabat, M. C. A., Taylor, S. L., \& Walter, T. S. (2004). Corporate governance, insider ownership and operating performance of Australian initial public offerings. Accounting and Finance, 44 (3), 299-328. http://dx.doi.org/10.1111/j.1467-629x.2004.00114.x

3. Blažek, L., Částek, O., Klapalová, A., Majerová, J., Pirožek, P., Sedláček, M., Šafrová Drášilová, A., \& Žáková Talpová, S. (2011). Nadnárodni společnosti v Céské republice II. Brno: Masarykova univerzita.

4. Boyd, B. K. (1994). Board Control and CEO Compensation. Strategic Management Journal, 15 (5), 335-344. http://dx.doi.org/10.1002/smj.4250150502 
5. Boyd, B. K. (1995). CEO Duality and Firm Performance: A Contingency Model. Strategic Management Journal, 16 (4), 301-312. http://dx.doi.org/10.1002/smj.4250160404

6. Brown, L. D., \& Caylor, M. L. (2009). Corporate governance and firm operating performance. Review of Quantitative finance and accounting, 32 (2), 129-144. http://dx.doi.org/10.1007/ s11156-007-0082-3

7. Core, J. E., Guay, W. R., \& Rusticus, T. O. (2006). Does weak governance cause weak stock returns? An examination of firm operating performance and investors' expectations. The Journal of Finance, 61 (2), 655-687. http://dx.doi.org/10.1111/j.1540-6261.2006.00851

8. Crosslan, C., \& Hambrick, D. C. (2007). How National Systems Differ in their Constraints on Corporate Executives: A Study of CEO in three Countries. Strategic Management Journal, 28 (8), 767-789. http://dx.doi.org/10.1002/smj.610

9. Dharwadkar, R., Goranova, M., Brandes, P., \& Khan, R. (2008). Institutional Ownership and Monitoring Effectiveness: It's Not Just How Much but What Else You Own. Organization Science, 19 (3), 419-440. http://dx.doi.org/10.1287/orsc.1080.0359

10. Elsayed, K. (2007). Does CEO Duality Really Affect Corporate Performance. Journal compilation, 15 (6), 1203-1214. http://dx.doi.org/10.1111/j.1467-8683.2007.00641.x

11. Fama, E., \& Jensen, M. C. (1983). Separation of ownership and control. Journal of law and economics, 26 (2), 301-325. http://dx.doi.org/10.1086/467037

12. Goranova, M., Alessandri, T. D., Brandes, P., \& Dharwadkar, R. (2007). Managerial ownership and corporate diversification: a longitual view. Strategic Management Journal, 28 (3), 211-225. http://dx.doi.org/10.1002/smj.570

13. Haniffa, R., \& Hudaib, M. (2006). Corporate governance structures and performance of Malaysian listed companies. Journal of Business Finance and Accounting, 33 (7/8), 1034-1062. http://dx.doi.org/10.1111/j.1468-5957.2006.00594.x

14. Harris, D., \& Helfat, C. E. (1998). CEO Duality, Succession, Capabilities and Agency Theory: Commentary and Research Agenda. Strategic Management Journal, 19 (9), 901-904. http://dx.doi.org/10.1002/(SICI)1097-0266(199809)19:9<901::AID-SMJ2>3.0.CO;2-V

15. Hashi, I. (2003). The legal framework for effective corporate governance: Comparative analysis of provisions in selected transition economies. Warsaw: Center for Social and Economic Research.

16. Horner, S. V. (2010). Board power, CEO appointments and CEO duality. Academy of Strategic Management Journal, 9 (2), 43-58.

17. Christensen, J., Kent, P., \& Stewart, J. (2010). Corporate governance and company performance in Australia. Australian Accounting Review, 20 (4), 372-386. http://dx.doi.org/10.1111/ j.1835-2561.2010.00108.x

18. Chung, K. H., \& Zhang, H. (2011). Corporate governance and institutional ownership. Journal of Financial and Quantitative Analysis, 46 (1), 247-273. http://dx.doi.org/10.1017/ S0022109010000682

19. Jensen M. C., \& Fuller, J. (2002). What's a Director to do? Harvard NOM Research Paper, 52 (02), 1-18. 
20. Kang, E., \& Zardkoohi, A. (2005). Board Leadership Structure and Firm Performance. Corporate Governance: An International Review, 13 (6), 785-799. http://dx.doi.org/10.1111/ j.1467-8683.2005.00470.x

21. Kiel, G. C., \& Nicholson, G. J. (2005). Board composition and corporate performance: How the Australian experienc informs contrasting theories of corporate governance. Corporate Governance: An International Review, 11 (3), 189-205. http://dx.doi.org/10.1111/14678683.00318

22. Kong-Hee, K., Hussam Al-Shammari, A., Bongjin, K., \& Seung-Hyun, L. (2009). CEO duality leadership and corporate diversification behavior. Journal of Business Research, 62 (11), 1173-1180. http://dx.doi.org/10.1016/j.busres.2008.10.017

23. Leech, N. L., \& Onwuegbuzie, A. J. (2009). A typology of mixed methods research designs. Quality \& quantity, 43 (2), 265-275. http://dx.doi.org/10.1007/s11135-007-9105-3

24. Lehmann, E., \& Weigand, J. (2000). Does the governed corporation perform better? Governance structures and corporate performance in Germany. European Finance Review, 4 (2), 157-195. http://dx.doi.org/10.1023/A:1009896709767

25. Meyer K. (2003). Corporate Governance in Transition economies. Journal of Financial Transformation, 9, 31-38.

26. Miller, D., \& Le Breton-Miller, I. (2006). Family governance and firm performance: Agency, stewardship, and capabilities. Family Business Review, 19 (1), 73-87. http://dx.doi. org/10.1111/j.1741-6248.2006.00063.x

27. Monem, R. (2011). Lessons for corporate governance. Australian Accounting Review, 21 (59), 340-351. http://dx.doi.org/10.1111/j.1835-2561.2011.00151.x

28. Muller-Kahle, M. I., \& Lewellyn, K. B. (2011). Did Board Configuration Matter? The Case of US Subprime Lenders. Corporate Governance: An International Review, 19 (5), 405-417. http://dx.doi.org/10.1111/j.1467-8683.2011.00871.x

29. Organisation for Economic Co-operation and Development. (2004). OECD Principles of Corporate Governance. Paris: Author.

30. Peng. M. W., Li, Y., Xie, E., \& Su, Z. (2010). CEO duality, organizational slack, and firm performance in China. Asia Pacific Journal of Management, 27 (4), 611-624. http://dx.doi. org/10.1007/s10490-009-9161-4

31. Pirožek, P. (2007). Současné přístupy ke správě a managementu společnosti. Acta Oeconomica Pragensia, 15 (3), 16-21.

32. Rodrigues, J. J. M., \& António, N. J. (2011). Managers' entrenchment, power and corporate governance. Euro Asia Journal of Management, 21 (40), 39-50.

33. Son A. L., Kroll M. J., \& Walters B. A. (2011). Stages of Corporate Governance in Transition Economies. Journal of Business Strategies, 28 (2), 151-176.

34. Tuggle, C. S., Sirmon, D. G., Reutzel, C. R., \& Bierman, L. (2010). Commanding board of director attention: investigating how organizational performance and CEO duality affect board members' attention to monitoring. Strategic Management Journal, 31 (9), 946-968. http://dx.doi.org/10.1002/smj.847 
35. Wright, M., Filatotchev, I., Hoskisson R.E., \& Peng, M.W. (2005). Strategy Research in Emerging Economies: Challenging the Conventional Wisdom. Journal of Management Studies, 42 (1), 1-33. http://dx.doi.org/10.1111/j.1467-6486.2005.00487.x

36. Teddlie, C., \& Yu, F. (2007). Mixed methods sampling. Journal of Mixed Methods Research, 1 (1), 77-100. http://dx.doi.org/10.1177/2345678906292430

37. Wright, M., Buck, T., \& Filatotchev, I. (2005). Corporate governance in transition economies. In Corporate governance. Accountability, enterprise and international comparison (415-445). Chichester: John Wiley \& Sons.

\section{Contact information}

Pavel Král, Stanislav Tripes, Pavel Pudil

University of Economics, Faculty of Management

Jarosovska 1117/II, 37701 Jindrichiov Hradec, Czech Republic

Email: kralpa@fm.vse.cz; tripes@fm.vse.cz;pudil@fm.vse.cz.

Petr Piro ̌̌ele

Masaryk University, Brno, Faculty of Economics and Administration

Lipová 41a, 60200 Brno-Pisárky, Czech Republic

E-mail:pirozek@econ.muni.cz.

JEL Classification: M1 